\title{
Analisis Struktur Kepemilikan Perusahaan Terhadap Profitabilitas Perusahaan Makanan dan Minuman yang Terdaftar di BEI
}

\author{
Heni Agustina, Djoko Soelistya \\ Universitas Nahdlatul Ulama Surabaya \\ e-mail: heni@unusa.ac.id, djoko_soelistya@unusa.ac.id
}

\begin{abstract}
The presence of food and beverage companies currently have an active role in the world economy, where the existence of such companies did not escape from the large number of funding. The funds obtained from some shareholders. Shareholding itself consists of managerial ownership, institutional ownership, and public ownership. This research is quantitative research using observation because it describes the relationships between variables through testing hypothesis. Samples taken from a population with specific criteria. The population in this study i.e. finance report food and beverage companies as much as 70 financial report of the food and beverage companies that are registered in BEI. The results in this study indicates that the managerial ownership variables have no effect on profitability, but institutional ownership and public ownership has an influence on profitability.
\end{abstract}

Keyword: production management, ownership, institutional ownership, public ownership, profitability

\section{PENDAHULUAN}

Keberadaan perusahaan makanan dan minuman di Indonesia sangatlah penting untuk keberlangsungan hidup masyarakatnya. Hal ini menyebabkan persaingan di dunia usaha makanan dan minuman semakin ketat dan banyak atau sedikit hal tersebut berdampak pada nilai profitabilitas perusahaan. Keberhasilan para pelaku usaha ini dapat tecermin bagaimana peranan kepemilikan perusahaan tersebut.

Jika perusahaan mengalami perkembangan maka tidak luput dari banyaknya struktur kepemilikan perusahaan yang terdapat dalam perusahaan. Kepemilikan ini dapat meningkatkan profitabilitas yang dimiliki perusahaan. Namun beberapa penelitian yang menyebutkan bahwa faktor kepemilikan managerial tidak memiliki pengaruh terhadap profitabilitas perusahaan. Hal ini berbanding terbalik akan kasus sevel di atas yang menunjukkan adanya peranan kepemilikan dalam kebangkrutan perusahaan.
Hal tersebut diungkapkan oleh peneliti Wismandana (2015), yang menyatakan bahwa kepemilikan manajerial terlalu rendah yang menyebabkan pengelolaan kinerja manajer menjadi kurang optimal dan sebagai pemegang saham minoritas, manajer belum dapat berpartisipasi dalam menentukan suatu keputusan dalam suatu perusahaan sehingga tidak memengaruhi profitabilitas.

\section{Rumusan Masalah}

1. Apakah kepemilikan manajerial perusahaan berpengaruh terhadap profitabilitas?

2. Apakah kepemilikan institusional perusahaan berpengaruh terhadap profitabilitas?

3. Apakah kepemilikan publik perusahaan berpengaruh terhadap profitabilitas?

\section{Tujuan Penelitian}

1. Untuk menguji pengaruh kepemilikan manajerial perusahaan terhadap profitabilitas. 
2. Untuk menguji pengaruh kepemilikan institusional perusahaan terhadap profitabilitas.

3. Untuk menguji pengaruh kepemilikan publik perusahaan terhadap profitabilitas.

\section{Manfaat Penelitian}

Penelitian ini diharapkan mampu untuk mengetahui pengaruh dari kepemilikan perusahaan terhadap profitabilitas pada perusahaan makanan dan minuman yang terdaftar di BEI.

\section{TINJAUAN TEORETIS DAN HIPOTESIS}

\section{Penelitian Terdahulu}

Tamba (2011) yang berjudul "Pengaruh Struktur Kepemilikan Terhadap Pengungkapan Tanggung Jawab Sosial Perusahaan (Studi Empiris pada Manufacturing Secondary Sectors yang Listing di BEI tahun 2009)". Penelitian ini menggunakan teknik analisis regresi linier berganda yang menunjukkan hasil bahwa variabel kepemilikan asing berpengaruh positif terhadap CSR, sedangkan kepemilikan institusional dan kepemilikan manajemen tidak berpengaruh terhadap CSR.

Penelitian Dewi (2008) yang berjudul "Pengaruh Kepemilikan Managerial, Kepemilikan Institusional, Kebijakan Hutang, Profitabilitas, dan Ukuran Perusahaan Terhadap Kebijakan Dividen”. Penelitian ini menggunakan teknik analisis regresi berganda yang menunjukkan hasil bahwa perusahaan kepemilikan saham oleh manajerial, kepemilikan saham institusional, kebijakan utang, dan profitabilitas yang semakin tinggi akan menurunkan kebijakan dividen.

\section{Struktur Kepemilikan}

Menurut Sugiarto (2009: 59) "struktur kepemilikan adalah struktur kepemilikan saham yaitu perbandingan jumlah saham yang dimiliki oleh orang dalam (insider) dengan jumlah saham yang dimiliki investor".

Pendapat lain juga mengungkapkan bahwa struktur kepemilikan merupakan pemisahan antara pemilik perusahaan dan manajer perusahaan. Pemilik atau pemegang saham adalah pihak yang menyertakan modal ke dalam perusahaan, sedangkan manajer adalah pihak yang ditunjuk pemilik dan diberi kewenangan mengambil keputusan dalam mengelola perusahaan, dengan harapan manajer dapat bertindak sesuai dengan kepentingan pemilik perusahaan (Sudana, 2011: 11).

\section{Jenis-Jenis Struktur Kepemilikan}

Struktur kepemilikan dapat dibedakan dengan beberapa jenis (Jensen, 1976) sebagai berikut.

1. Kepemilikan manajerial, yaitu merupakan kepemilikan saham oleh pihak manajemen perusahaan. Kepemilikan manajerial ini manajer dapat langsung merasakan manfaat dari keputusan yang diambil dan manajer yang menanggung risiko apabila ada kerugian yang timbul sebagai konsekuensi dari pengambilan keputusan yang salah.

2. Kepemilikan institusional, yaitu merupakan kepemilikan saham oleh perusahaan lain atau lembaga lain. Kepemilikan institusi adalah salah satu alat yang digunakan untuk mengurangi agency conflict. Dengan tingkat kepemilikan institusional yang tinggi maka akan menimbulkan usaha pengawasan yang lebih besar oleh pihak investor institusional sehingga dapat menghalangi perilaku oportunistis yang dilakukan oleh pihak manajer serta mengurangi tingkat penyelewengan yang dilakukan oleh manajemen yang dapat menurunkan nilai dari perusahaan. 
3. Kepemilikan publik, merupakan persentase kepemilikan saham yang memiliki oleh pihak luar (outsider ownership). Pendapat lain mengungkapkan bahwa kepemilikan saham perusahaan oleh masyarakat umum atau oleh pihak luar (Febriana, 2010).

\section{Profitabilitas}

Menurut Gitman (2009:56) menyatakan bahwa profitabilitas merupakan hubungan antara pendapatan dan biaya yang dihasilkan dengan menggunakan aset perusahaan, baik lancar maupun tetap dalam aktivitas produksi. Hal yang sama juga dikemukakan oleh Muslich (2003) yang menyatakan bahwa profitabilitas adalah kemampuan perusahaan untuk memperoleh laba dari kegiatan bisnis yang dilakukan. Dengan kata lain, profitabilitas merupakan alat pengukur tingkat keuntungan yang dihasilkan oleh perusahaan.

\section{Ukuran Profitabilitas}

Ukuran rasio profitabilitas yang lazim digunakan yaitu return on investment (ROI) dan return on equity (ROE) (Muslich, 2003).

1. Return on investment menunjukkan suatu ukuran dari produktivitas aktiva dalam memberikan pengembalian atas investasi pemegang saham dan kreditor. Rasio ini dapat dikatakan sama dengan rasio return on asset (ROA) rasio yang mengukur laba bersih setelah pajak dengan penjualan.

2. Return on equity menunjukkan suatu efektivitas perusahaan dalam mengelola modal sendiri dan mengukur tingkat keuntungan dari investasi yang dilakukan oleh pemilik modal sendiri maupun pemegang saham.

Salah satu rasio return on asset (ROA) dapat menggambarkan bagaimana perkembangan profitabilitas perusahaan.

\section{HIPOTESIS}

\section{Kepemilikan Manajerial Terhadap Profitabilitas}

Menurut Brochet (2004), manajemen yang memiliki saham perusahaan dapat memberikan informasi lebih banyak tentang perusahaan dibandingkan dengan pemegang saham non-institusi lainnya, dengan demikian memiliki kesempatan untuk melakukan kontrol dari profitabilitas perusahaan. Pendapat Listyani (2003) bahwa kepemilikan saham manajerial akan mendorong manajer untuk dapat berhati-hati dalam mengambil keputusan karena mereka ikut merasakan secara langsung manfaat dari keputusan yang diambil dan turut serta merasakan konsekuensi dari pengambilan keputusan yang salah.

Berdasarkan teori di atas menunjukkan bahwa kepemilikan manajerial pada suatu perusahaan memiliki peranan penting dalam menentukan profitabilitas.

H1: kepemilikan manajerial memiliki pengaruh terhadap profitabilitas.

\section{Kepemilikan Institusional Terhadap Profitabilitas}

Pada penelitian di negara Kenya menunjukkan hasil bahwa struktur kepemilikan memiliki pengaruh yang signifikan terhadap kinerja keuangan (Gitundu, 2016). Di dalam penelitian disebutkan bahwa kepemilikan individu memiliki pengaruh yang positif terhadap kinerja keuangan (ROA). Tamba (2011) berpendapat bahwa peningkatan kepemilikan institusional menjadikan pengawasan yang ketat terhadap kinerja manajemen sehingga manajemen akan menghindari perilaku yang merugikan prinsipal.

Menurut Jensen (1976) berpendapat bahwa kepemilikan institusional mempunyai peran penting dalam meminimalkan konflik keagenan yang terjadi antara pemegang saham dengan manajer. 
$\mathrm{H} 2$ : kepemilikan institusional berpengaruh terhadap profitabilitas.

\section{Kepemilikan Publik Terhadap Profitabilitas}

Jensen (1976) berpendapat bahwa konflik kepentingan yang sangat potensial ini menyebabkan pentingnya suatu mekanisme yang diterapkan yang dapat berguna untuk melindungi kepentingan pemegang saham.

Menurut Arifulsyah (2016) bahwa semakin tinggi pertanggungjawaban sosial perusahaan, dapat membuat semakin tinggi pula kepercayaan masyarakat terhadap perusahaan, dan hal tersebut pula dapat secara otomatis dapat meningkatkan kinerja keuangan perusahaan tersebut. Selain itu, CSR adalah variabel yang dapat memperkuat pengaruh antara besaran kepemilikan publik terhadap kinerja keuangan perusahaan. Dengan adanya CSR perusahaan dapat membuat masyarakat publik semakin mudah untuk mempercayakan investasi mereka ke perusahaan yang dapat membuat kinerja keuangan perusahaan ikut meningkat pula.

H3: kepemilikan publik berpengaruh terhadap profitabilitas

\section{METODE PENELITIAN}

\section{Populasi dan Sampel Penelitian}

Populasi yang digunakan dalam penelitian ini adalah data laporan keuangan perusahaan makanan dan minuman yang terdaftar di Bursa Efek Indonesia tahun 2010 sampai dengan tahun 2016, tercatat sebanyak 18 perusahaan sehingga populasi yang digunakan adalah 126 data laporan keuangan. Teknik yang digunakan untuk menentukan sampel dalam penelitian ini adalah purposive sampling yaitu teknik penarikan sampel non probabilitas yang menyeleksi responden- responden berdasarkan ciri-ciri atau sifat khusus yang dimiliki oleh sampel dan sampel tersebut yang merupakan representatif dari populasi (Sumarsono, 2004:52). Berdasarkan beberapa kriteria, maka jumlah sampel yang digunakan dalam penelitian ini adalah 10 perusahaan sehingga sampel yang digunakan adalah 70 data laporan keuangan.

\section{Jenis Sumber Data}

Data yang digunakan adalah data sekunder yaitu dengan menyeleksi laporan keuangan perusahaan makanan dan minuman yang terdaftar di Bursa Efek Indonesia tahun 2010 sampai 2016.

\section{Definisi dan Pengukuran Variabel}

Variabel-variabel yang digunakan dalam penelitian ini adalah sebagai berikut.

\section{Variabel Terikat (Y)}

\section{Profitabilitas}

Profitabilitas yang dimaksud diproyeksikan dengan return on asset (ROA) yang diperoleh perusahaan yaitu rasio pendapatan setelah bunga dan pajak (EAT) atau net pendapatan dibagi dengan nilai buku aset di awal tahun fiskal (Brigham, 2005). Berikut ini merupakan perhitungan ROA:

ROA $=\frac{\text { Laba setelah Pajak }}{\text { Total Aset }}$

\section{Variabel Bebas (X)}

a. Kepemilikan manajerial

Kepemilikan manajerial dapat diukur dengan menggunakan rasio antara jumlah saham yang dimiliki manajer atau direksi dan dewan 
Heni Agustina, Djoko Soelistya, Analisis Struktur Kepemilikan Perusahaan Terhadap Profitabilitas Perusahaan Makanan dan Minuman yang Terdaftar di BEI

komisaris terhadap total saham yang beredar (Rustendi, 2008).

Kepemilikan Manajerial $=\frac{\text { Jumlah Saham Pihak }}{\text { Total Saham Beredar }} \times 100$

b. Kepemilikan institusional

Menurut Ujiyantho (2007) kepemilikan institusional memiliki proporsi kepemilikan saham oleh institusi lain. Kepemilikan institusional dapat diukur dengan rasio antara jumlah lembar saham yang dimiliki oleh institusi terhadap jumlah lembar saham yang beredar secara keseluruhan.

Kepemilikan Manajerial $=\frac{\text { Jumlah Saham Pihak }}{\text { Total Saham Beredar }} \times 100$

c. Kepemilikan publik

Kepemilikan publik merupakan saham yang telah dimiliki oleh publik, kepemilikannya bisa oleh sebuah grup yang besar yang tidak ada hubungannya antara individu dan atau lembaga investasi (Sundjaja, 2003). Kepemilikan publik dapat diukur dengan rasio antara jumlah lembar saham yang dimiliki oleh publik terhadap jumlah lembar saham yang beredar secara keseluruhan.

Kepemilikan Manajerial $=\frac{\text { Jumlah Saham Pihak }}{\text { Total Saham Beredar }} \times 100$

\section{Metode Analisis Data}

Analisis data yang digunakan menggunakan metode analisis regresi linier berganda dengan menggunakan bantuan SPSS.18. Model regresi yang digunakan untuk menguji hipotesis adalah sebagai berikut.

$$
\mathrm{Y}=\beta_{0}+\beta_{1} \mathrm{X}_{1}+\beta_{2} \mathrm{X}_{2}+\beta_{3} \mathrm{X}_{3}+\mathrm{e}
$$

Di mana:

$\mathrm{Y}=$ Return on asset

$\mathrm{X}_{1} \quad=$ Kepemilikan manajerial

$$
\begin{array}{ll}
\mathrm{X}_{2} & =\text { Kepemilikan institusional } \\
\mathrm{X}_{3} & =\text { Kepemilikan publik } \\
\beta_{0} & =\text { Konstanta } \\
\beta_{1}, \beta_{2}, \beta_{3} & =\text { Koefisien regresi } \mathrm{X}_{1}, \mathrm{X}_{2}, \mathrm{X}_{3} \\
\mathrm{e} & =\text { Faktor pengganggu/variabel error }
\end{array}
$$

\section{PEMBAHASAN}

\section{Analisis Statistik Deskriptif}

Statistik deskriptif digunakan untuk memberikan informasi, menyajikan dan menganalisis mengenai data yang dimiliki. Alat analisis yang digunakan dalam penelitian ini yaitu rata-rata (mean) dan standard deviation. Deskripsi dari masing-masing variabel dijelaskan sebagai berikut.

\section{Tabel 4.2 Statistik Deskriptif}

Descriptive Statistics

\begin{tabular}{|l|l|r|r|}
\hline & Mean & Std. Deviation & \multicolumn{1}{|c|}{ N } \\
\hline ROA & 2.2901 & .78068 & 63 \\
Kepemilikan Manajerial & 2.7505 & 6.10920 & 63 \\
Kepemilikan Institusional & 4.1713 & .33989 & 63 \\
Kepemilikan Publik & 3.0621 & .86381 & 63 \\
\hline
\end{tabular}

Sumber: Data sekunder yang diolah SPSS

Berdasarkan Tabel 4.2 dapat diketahui jumlah pengamatan yang diteliti sebanyak 70 pengamatan, berdasarkan 10 perusahaan selama tujuh tahun yaitu 2010, 2011, 2012, 2013, 2014, 2015, 2016. Dalam Tabel 4.2 terlihat bahwa ROA memiliki mean sebesar 2,22901 dengan standard deviation sebesar 0,78069. Dalam Tabel 4.2 terlihat bahwa kepemilikan manajerial memiliki mean sebesar 2,7505 dengan standard deviation sebesar 6,10920. Dalam Tabel 4.2 terlihat bahwa kepemilikan institusional memiliki mean sebesar 4,1713 dengan standard deviation sebesar 0,33989. Dalam Tabel 4.2 terlihat bahwa kepemilikan publik memiliki mean sebesar 3,0621 dengan standard deviation sebesar 0,86381 . 


\section{Uji Normalitas}

Uji normalitas diperlukan untuk memastikan bahwa sebaran data yang digunakan bersifat normal. Untuk mengetahui apakah data tersebut mengikuti sebaran normal dapat diuji dengan metode Kolmogorov Smirnov (Sumarsono, 2004: 43). Data terdistribusi normal apabila hasil Kolmogorov-Smirnov menunjukkan nilai signifikan di atas 0,05 .

Tabel 4.3 Kolmogorov-Smirnov Test

One-Sample Kolmogorov-Smirnov Test

\begin{tabular}{|ll|r|}
\hline & & $\begin{array}{c}\text { Unstandardized } \\
\text { Residual }\end{array}$ \\
\hline $\mathrm{N}$ & Mean & 63 \\
Normal Parameters ${ }^{\mathrm{a}, \mathrm{b}}$ & Std. & $0 \mathrm{E}-7$ \\
& Deviation & .65350955 \\
& Absolute & .121 \\
Most Extreme Differences & Positive & .121 \\
& Negative & -.065 \\
Kolmogorov-Smirnov Z & & .964 \\
Asymp. Sig. (2-tailed) & & .311 \\
\hline
\end{tabular}

a. Test distribution is normal.

b. Calculated from data.

Sumber: Data sekunder yang diolah SPSS

Berdasarkan Tabel 4.3 menunjukkan bahwa nilai signifikan sebesar 0,970 yang lebih besar dari 0,05 maka data dalam penelitian ini berdistribusi normal setelah melakukan transform data.

\section{Uji Asumsi Klasik}

\section{Uji Multikolinieritas}

Multikorelasi bertujuan untuk menguji apakah model regresi ditemukan adanya korelasi antar-variabel bebas (independen). Cara untuk mengetahui apakah terjadi multikolonieritas atau tidak yaitu dengan melihat nilai tolerance dan variance inflation factor (VIF).
Tabel 4.4 Hasil Uji Multikolonieritas

\begin{tabular}{|c|c|c|c|c|c|c|c|}
\hline \multicolumn{8}{|c|}{ Coefficients $^{\mathrm{a}}$} \\
\hline \multirow{2}{*}{ Model } & \multicolumn{2}{|c|}{$\begin{array}{c}\text { Unstandardized } \\
\text { Coefficients }\end{array}$} & \multirow{2}{*}{\begin{tabular}{|c|}
$\begin{array}{c}\text { Standardized } \\
\text { Coefficients }\end{array}$ \\
Beta \\
\end{tabular}} & \multirow{2}{*}{$t$} & \multirow{2}{*}{ Sig. } & \multicolumn{2}{|c|}{$\begin{array}{c}\text { Collinearity } \\
\text { Statistics }\end{array}$} \\
\hline & B & \begin{tabular}{|l|} 
Std. \\
Error
\end{tabular} & & & & Tolerance & VIF \\
\hline (Constant) & -11.966 & 2.888 & & -4.144 & .000 & & \\
\hline $\begin{array}{l}\text { Kepemilikan } \\
\text { Manajerial }\end{array}$ & .019 & .015 & .152 & 1.262 & .212 & .817 & 1.224 \\
\hline $\begin{array}{l}\text { Kepemilikan } \\
\text { Institusional }\end{array}$ & 2.668 & .552 & 1.162 & 4.835 & .000 & .206 & 4.860 \\
\hline Kepemilikan Publik & 1.004 & .207 & 1.110 & 4.855 & .000 & .227 & 4.404 \\
\hline
\end{tabular}

Dari hasil tersebut menunjukkan bahwa nilai tolerance dari variabel kepemilikan manajerial, kepemilikan institusional, dan kepemilikan publik memiliki nilai tolerance yang lebih besar dari 0,10 dan memiliki nilai VIF yang lebih kecil dari 10. Hasil tersebut menunjukkan bahwa tidak adanya gejala multikolinieritas.

\section{Uji Heterokedastisitas}

Pengujian ini dilakukan dengan menggunakan Scatter Plot. Dinyatakan tidak terjadi heteroskedastisitas yaitu apabila tidak ada pola yang jelas, serta titik-titik menyebar di atas dan di bawah angka 0 pada sumbu Y.

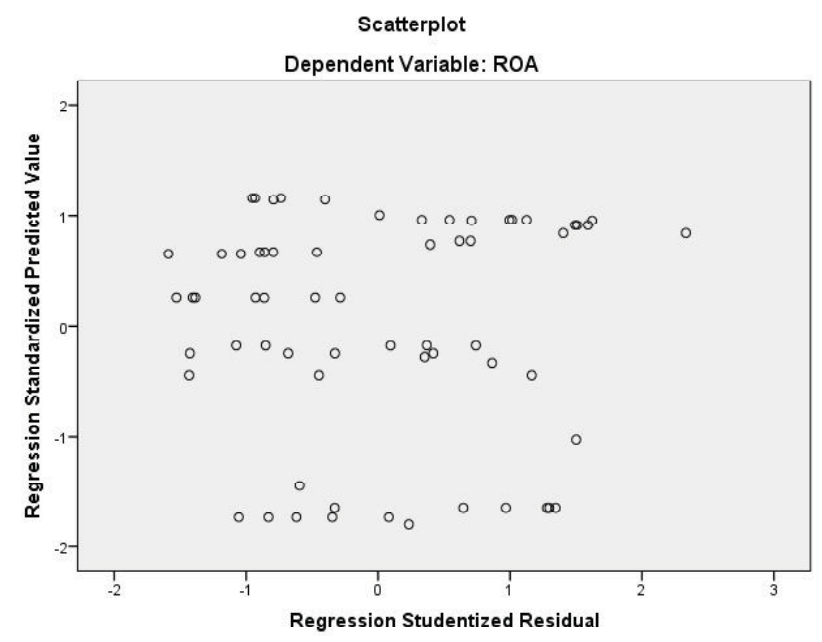

Gambar 4.1 Hasil Uji Heterokedastisitas

Sumber: Data sekunder yang diolah SPSS

Hasil pengujian pada gambar tersebut menunjukkan bahwa pola Scatter Plot dari regresi 
menyebar. Hal ini menunjukkan bahwa tidak adanya gejala heteroskedastisitas.

\section{Uji Autokorelasi}

Uji autokorelasi bertujuan menguji apakah dalam suatu model linier ada korelasi antara korelasi pengganggu periode $t$ dengan kesalahan pada periode t-1 (sebelumnya). Pengujian ini dilakukan dengan menggunakan uji Durbin-Watson.

\section{Tabel 4.5 Hasil Uji Durbin-Watson}

\section{Model Summary ${ }^{\mathrm{b}}$}

\begin{tabular}{|c|c|r|r|r|r|}
\hline Model & $\mathrm{R}$ & $\mathrm{R}$ Square & $\begin{array}{l}\text { Adjusted } \\
\text { R Square }\end{array}$ & $\begin{array}{l}\text { Std. Error of } \\
\text { the Estimate }\end{array}$ & $\begin{array}{r}\text { Durbin- } \\
\text { Watson }\end{array}$ \\
\hline 1 & $.547^{\mathrm{a}}$ & .299 & .264 & .66992 & .628 \\
\hline
\end{tabular}

a. Predictors: (constant), kepemilikan Publik, kepemilikan manajerial, kepemilikan institusional

b. Dependent variable: ROA

Sumber: Data sekunder yang diolah SPSS

Berdasarkan hasil pengujian tersebut nilai Durbin-Watson sebesar 0,628 yang artinya nilai DW berada di antara -2 sampai +2 maka dapat disimpulkan tidak ada masalah autokorelasi.

\section{Uji F}

Uji $\mathrm{F}$ ini dilakukan untuk menguji sesuai tidaknya model regresi yang dihasilkan guna menyesuaikan variabel $\mathrm{X}_{1}$ (kepemilikan manajerial), $X_{2}$ (kepemilikan institusional), $X_{3}$ (kepemilikan publik) terhadap Y (ROA) pada perusahaan food and beverage yang terdaftar di Bursa Efek Indonesia.

Tabel 4.6 Hasil Uji F ANOVA $^{\mathrm{a}}$

\begin{tabular}{|l|r|r|r|c|c|}
\hline Model & $\begin{array}{c}\text { Sum of } \\
\text { Squares }\end{array}$ & Df & $\begin{array}{c}\text { Mean } \\
\text { Square }\end{array}$ & F & Sig. \\
\hline Regression & 11.308 & 3 & 3.769 & 8.399 & $.000^{\mathrm{b}}$ \\
1 Residual & 26.479 & 59 & .449 & & \\
Total & 37.786 & 62 & & & \\
\hline
\end{tabular}

a. Dependent variable: ROA

b. Predictors: (constant), kepemilikan publik, kepemilikan manajerial, dan kepemilikan institusional Sumber: Data sekunder yang diolah SPSS
Berdasarkan Tabel 4.6 menunjukkan bahwa nilai uji $\mathrm{F}$ sebesar 8.399 dengan probabilitas 0,000 . Berdasarkan nilai probabilitas tersebut lebih kecil dari 0,05 maka berarti variabel independen yang terdiri dari kepemilikan manajerial, kepemilikan institusional, dan kepemilikan publik secara bersama-sama berpengaruh positif terhadap ROA.

\section{Uji t}

Uji t ini dilakukan untuk mengetahui dan membuktikan pengaruh secara parsial kepemilikan manajerial, kepemilikan institusional, dan kepemilikan publik terhadap ROA perusahaan food and beverage yang terdaftar di Bursa Efek Indonesia.

Tabel 4.7 Hasil Uji T

Coefficients $^{\mathrm{a}}$

\begin{tabular}{|c|c|c|c|c|c|c|c|}
\hline \multirow{2}{*}{ Model } & \multicolumn{2}{|c|}{$\begin{array}{l}\text { Unstandardized } \\
\text { Coefficients }\end{array}$} & \multirow{2}{*}{\begin{tabular}{|c|} 
Standardized \\
Coefficients
\end{tabular}} & \multirow{2}{*}{$\mathrm{t}$} & \multirow{2}{*}{ Sig. } & \multicolumn{2}{|c|}{$\begin{array}{c}\text { Collinearity } \\
\text { Statistics }\end{array}$} \\
\hline & B & $\begin{array}{l}\text { Std. } \\
\text { Error }\end{array}$ & & & & Tolerance & VIF \\
\hline (Constant) & -11.966 & 2.888 & & -4.144 & .000 & & \\
\hline${ }_{1}$ Kepemilikan Manajerial & .019 & .015 & .152 & 1.262 & .212 & .817 & 1.224 \\
\hline Kepemilikan Institusional & 2.668 & .552 & 1.162 & 4.835 & .000 & .206 & 4.860 \\
\hline Kepemilikan Publik & 1.004 & 207 & 1.110 & 4.855 & .000 & 227 & 4.404 \\
\hline
\end{tabular}

Sumber: Data sekunder yang diolah SPSS

Persamaan regresi model 1 dapat ditulis sebagai berikut:

ROA $=-11.966+0,019$ Kepemilikan Manajerial $+2,668$ Kepemilikan Institusional $+2,004$ Kepemilikan Publik $+\varepsilon$

Pengujian hipotesis 1 mengenai pengaruh kepemilikan manajerial terhadap ROA menunjukkan nilai t hitung sebesar 1,262 dengan signifikansi sebesar 0,212 ( $\mathrm{p}>0,05)$. Hal ini berarti bahwa kepemilikan manajerial tidak berpengaruh terhadap ROA. Hipotesis 1 ditolak.

Pengujian hipotesis 2 mengenai pengaruh kepemilikan institusional terhadap ROA menun- 
jukkan thitung sebesar 4,835 dengan signifikansi sebesar 0,000 ( $\mathrm{p}<0,05)$. Hal ini berarti bahwa kepemilikan institusional berpengaruh terhadap ROA. Hipotesis 2 diterima.

Pengujian hipotesis 3 mengenai pengaruh kepemilikan publik terhadap ROA menunjukkan bahwa nilai t hitung sebesar 4,855 dengan signifikansi sebesar $0,000(\mathrm{p}<0,05)$. Hal ini berarti bahwa kepemilikan publik berpengaruh positif terhadap ROA. Hipotesis 3 diterima.

\section{Koefisien Determinasi}

Koefisien determinasi $\left(\mathrm{R}^{2}\right)$ pada intinya mengukur seberapa jauh kemampuan model dalam menerangkan variasi variabel independen.

Tabel 4.8

Hasil Koefisien Determinasi $\left(\mathbf{R}^{2}\right)$

Model Summary ${ }^{\mathrm{b}}$

\begin{tabular}{|c|c|r|r|r|r|}
\hline Model & $\mathbf{R}$ & $\begin{array}{c}\text { R } \\
\text { Square }\end{array}$ & $\begin{array}{l}\text { Adjusted } \\
\text { R Square }\end{array}$ & $\begin{array}{l}\text { Std. Error of } \\
\text { the Estimate }\end{array}$ & $\begin{array}{l}\text { Durbin- } \\
\text { Watson }\end{array}$ \\
\hline 1 & $.547^{\mathrm{a}}$ & .299 & .264 & .66992 & .628 \\
\hline
\end{tabular}

a. Predictors: (constant), kepemilikan publik, kepemilikan manajerial, kepemilikan institusional

b. Dependent variable: ROA

Sumber: Data sekunder yang diolah SPSS

Dari hasil pengujian tersebut diperoleh nilai adjusted R2 sebesar 0,264. Hal ini menunjukkan bahwa sebesar 26,4\% variasi kinerja ROA dapat dijelaskan oleh struktur kepemilikan yang terdiri dari kepemilikan manajerial, kepemilikan institusional, kepemilikan publik sedangkan 73,6\% lainnya dapat dijelaskan oleh variabel-variabel lainnya di luar model ini.

\section{KESIMPULAN}

Berdasarkan uraian dan analisis data yang telah dikemukakan pada bab sebelumnya, maka dapat ditarik kesimpulan sebagai berikut.
1. Kepemilikan manajerial tidak berpengaruh terhadap ROA. Hipotesis 1 ditolak. Hal ini menunjukkan bahwa kepemilikan saham oleh pihak manajerial masih belum dapat menyatukan kepentingan manajer dengan shareholder yang lain, sehingga kepemilikan manajerial tidak begitu berpengaruh terhadap return on asset (ROA). Hasil Penelitian ini sejalan dengan penelitian yang dilakukan oleh Wiranata dan Nugrahanti (2013) Namun, menurut Aji (2016) berpendapat bahwa, keputusan manajerial dipandu oleh kepentingan mereka sendiri dari pada kepentingan pemilik perusahaan.

2. Kepemilikan institusional berpengaruh terhadap ROA. Hipotesis 2 diterima. Hal ini menunjukkan bahwa Proporsi kepemilikan institusional yang besar dapat meningkatkan usaha pengawasan oleh pihak institusi sehingga dapat menghalangi perilaku oportunistis manajer dan dapat membantu pengambilan keputusan perusahaan, sehingga dapat meningkatkan kinerja keuangan perusahaan yang diukur dengan ROA. Penelitian ini didukung oleh Kumai et al. (2014), Sekaredi (2011) yang menyatakan bahwa terdapat pengaruh yang positif dan signifikan antara kepemilikan institusional dan ROA.

3. Kepemilikan publik berpengaruh positif terhadap ROA. Hipotesis 3 diterima. Hal ini menunjukkan bahwa meningkatnya kepemilikan publik disebabkan adanya perlindungan hukum terhadap pemegang perusahaan dan keterbukaan informasi kepada publik. Meningkatnya kepemilikan publik menunjukkan adanya sistem corporate governance yang baik. Oleh karena itu, kepemilikan publik diharapkan dapat meningkatkan kinerja perusahaan. Penelitian ini sejalan dengan Wati (2017) yang menyatakan bahwa terdapat 
pengaruh yang positif dan signifikan antara kepemilikan publik dan ROA.

\section{SARAN}

Berdasarkan hasil analisis dan kesimpulan yang telah diperoleh, peneliti menyarankan sebagai berikut.

1. Pihak perusahaan makanan dan minuman yang terdaftar di BEI sebaiknya meningkatkan peranan dalam kepemilikan sahamnya. Karena dapat meningkatkan profitabilitas yang diukur dengan nilai ROA perusahaan.

2. Untuk peneliti selanjutnya hendaknya dapat menambahkan beberapa faktor lain yang dapat mendukung profitabilitas perusahaan.

\section{DAFTAR RUJUKAN}

Aji, Dhamar Yudho dan Aria Farah Mita. 2010. Pengaruh Profitabilitas, Risiko Keuangan, Nilai Perusahaan, dan Struktur Kepemilikan Terhadap Praktik Perataan Laba: Studi Empiris Perusahaan Manufaktur yang Terdaftar di Bei. Simposium Nasional Akuntansi Xiii, Purwokerto.

Arifulsyah, Hamdani. 2016. "Pengaruh Proporsi Kepemilikan Publik Terhadap Kinerja Keuangan Perusahaan, dengan CSR Disclosure Sebagai Variabel Moderating”. Jurnal Akuntansi Keuangan dan Bisnis, Vol. 9. Jurnal Politeknik Caltex Riau.

Brigham, E.F., Ehrhardt, M.C. 2005. Financial Management Theory and Practice, Eleventh Edition, Ohio: South Western Cengage Learning.

Brochet, Franchois dan Zhan Gildao. 2004. "Managerial Entrachment and Earnings Smoothing”. Working Paper.
Dewi, Sisca Chirstianty. 2008. "Pengaruh Kepemilikan Managerial, Kepemilikan Institusional, Kebijakan Hutang, Profitabilitas, dan Ukuran Perusahaan Terhadap Kebijakan Dividen”. Jurnal Bisnis dan Akuntansi, Vol.10, No.1.

Febriana, Louw. 2010. Kajian Corporate Governance dan Likuiditas Terhadap kinerja Keuangan pada Sektor Property \& Real Estate. Pontianak: STIE Widya Dharma.

Gitman, Lawrence. 2009. Principles of Manajerial Finance. United States: Pearson Addison Wesley.

Jensen, M.C. and Meckling, W.H. 1976. "Theory of the Firm: Managerial Behavior, Agency Costs and Ownership Structure”. Journal of Financial Economics.

Listyani, Theresia Tyas. 2003. Kepemilikan Manajerial, Kebijakan Hutang, dan Pengaruhnya Terhadap Kepemilikan Saham Institusional (Studi pada Perusahaan Manufaktur di Bursa Efek di Jakarta). Jurnal Ekonomi dan Bisnis Indonesia, Vol.15, No.4, 2000.

Muslich, Mohamad. 2003. Manajemen Keuangan Modern. Jakarta: Bumi Aksara.

Rustendi, Tedi dan Farid Jimmi. 2008. Pengaruh Hutang dan Kepemilikan Manajerial Terhadap Nilai Perusahaan pada Perusahaan Manufaktur (Survei pada Perusahaan Manufaktur yang Tercatat di Bursa Efek Jakarta). Jurnal Akuntansi FE Unsil.

Sudana, I. 2011. Manajemen Keuangan Perusahaan Teori dan Praktik. Jakarta: Erlangga. Sugiarto. 2009. Struktur Modal, Struktur Kepemilikan Perusahaan, Permasalahan Keagenan, dan Informasi Asimetri. Yogyakarta: Graha Ilmu. 
Sumarsono, H.M. Sonny. 2004. Metode Riset Sumber Daya Manusia. Jember: Graha Ilmu.

Sundjaja Ridwan S. dan Inge Barlian. 2003. Manajemen Keuangan 1, Edisi kelima. Jakarta: Literata Lintas Media.

Tamba, Erida Gabriella Handayani. 2011. Pengarub Struktur Kepemilikan Terhadap Pengungkapan Tanggung Jawab Sosial Perusahaan (Studi Empiris pada Perusahaan Manufacturing Secondary Sectors yang Listed di BEI tahun 2009). Semarang: FEB Universitas Diponegoro.
Wiranata, Yulius Ardy dan Yeterina Widi Nugrahanti. 2013. Pengaruh Struktur Kepemilikan Terhadap Profitabilitas Perusahaan Manufaktur di Indonesia. Jurnal Akuntansi dan Keuangan, Vo. 15, No. 1, ISSN 14110288 print/ISSN 2338-8137.

Wismandana, Nicho Budi. 2015. "Pengaruh Corporate Social Responsibility, Kepemilikan Manajerial, dan Kepemilikan Institusional Terhadap Profitabilitas Perusahaan”. STIESIA. Jurnal Ilmu \& Riset Akuntansi, Vol. 4, No. 12. 